\title{
LIVER HISTOLOGY IN CO-INFECTION OF HEPATITIS C VIRUS (HCV) AND HEPATITIS G VIRUS (HGV)
}

\author{
Edna STRAUSS(1), Luiz Carlos da Costa GAYOTTO(1), Fabian FAY(2), Oscar FAY(2), Helena Sabino FERNANDES(3) \& Dalton de Alencar Fischer CHAMONE (3)
}

\begin{abstract}
SUMMARY
As little is known about liver histology in the co-infection of hepatitis $\mathrm{C}$ virus (HCV) and hepatitis $\mathrm{G}$ virus (HGV), HGV RNA was investigated in 46 blood donors with hepatitis C, 22 of them with liver biopsy: co-infection HCV / HGV $(n=6)$ and HCV isolated infection $(n=16)$. Besides staging and grading of inflammation at portal, peri-portal and lobular areas (Brazilian Consensus), the fibrosis progression index was also calculated. All patients had no symptoms or signs of liver disease and prevalence of HGV / HCV co-infection was $15.2 \%$. Most patients had mild liver disease and fibrosis progression index, calculated only in patients with known duration of infection, was 0.110 for co-infection and 0.130 for isolated HCV infection, characterizing these patients as "slow fibrosers". No statistical differences could be found between the groups, although a lesser degree of inflammation was always present in coinfection. In conclusion co-infection HCV / HGV does not induce a more aggressive liver disease, supporting the hypothesis that $\mathrm{HGV}$ is not pathogenic.
\end{abstract}

KEYWORDS: Hepatitis C; Hepatitis G; Liver fibrosis; Inflammatory activity.

\section{INTRODUCTION}

Hepatitis $\mathrm{C}$ virus (HCV) and hepatitis $\mathrm{G}$ virus (HGV) are RNA viruses of the flaviviridae family that can be transmitted by blood transfusion and other parenteral and non-parenteral routes, with persistence of viremia ${ }^{3,16}$. The high prevalence of HCV infection and its morbidity is very well documented, as well as its relation to acute and chronic hepatitis, cirrhosis and hepatocellular carcinoma ${ }^{2,25}$. As for HGV, a virus more recently described, there are few evidences of morbidity and many doubts about its etiologic role in liver diseases ${ }^{17,27}$.

The prevalence of $\mathrm{HGV}$ in blood donors is 1.5 to $1.7 \%$ in the United States, but among them only $50 \%$ have elevated $\mathrm{ALT}^{3}$. Many studies have detected the HGV-RNA in patients with chronic hepatitis and even some cryptogenic cirrhosis ${ }^{19}$, but the initial reports of HGV having an etiologic role in fulminant hepatitis were not confirmed in well conducted studies $^{13}$.

Co-infection by HCV and HGV has been studied in chronic hepatitis submitted to Interferon treatment ${ }^{11}$, in serum and liver of deceased drug users $^{23}$, in association with cryoglobulinemia ${ }^{26}$, after bone marrow transplantation ${ }^{22}$ and also in terminal liver disease, before and after hepatic transplantation ${ }^{5}$. More recently, it was demonstrated that co-infection of $\mathrm{HGV}$ in HIV patients reduces mortality ${ }^{29}$, due to inhibition of HIV replication $^{30}$. Histopathological variables, however, are seldom analyzed. In one of these studies histological severity of the underlying chronic hepatitis did not differ according to the HGV status, but hepatitis activity was moderately increased in patients with associated HIV infection ${ }^{28}$.

Taking in consideration the recent classifications of chronic hepatitis in which the stage of the disease is analyzed separately from necroinflammatory activity, the grading of which is evaluated in portal, peri-portal and lobular areas, it is worthwhile to investigate liver histology in co-infection by HCV and HGV. As the prevalence of hepatitis G is particularly high in Brazilian blood donors ${ }^{15}$, and hepatitis $\mathrm{C}$ infection is usually mild in these asymptomatic patients, this is an interesting group to investigate a possible synergism of both viruses in the production of liver damage.

\section{PATIENTS AND METHODS}

The subjects were 46 blood donors investigated due to hepatitis $\mathrm{C}$ positive tests. An epidemiological questionnaire was applied to detect the possible source of infection as well as its duration in years. Liver enzymes, namely ALT, GGT and other laboratorial tests were performed initially and every 2 or 3 months in the follow up in order to decide about liver biopsy and treatment. All the patients had no symptoms or signs of liver disease and were anti-HCV positive by ELISA II test confirmed by Immuno blotting test RIBA II. HGV-RNA was measured by nested polymerase chain reaction using primers from the NS5 region of the genome of $\mathrm{HGV}$.

\footnotetext{
(1) Divisão de Anatomia Patológica da FMUSP and LIM 14, São Paulo, SP, Brasil.

(2) Centro de Tecnologia en Salud Publica, Universidade Nacional de Rosário, Argentina.

(3) Fundação Pró-Sangue Hemocentro de São Paulo, SP, Brasil.

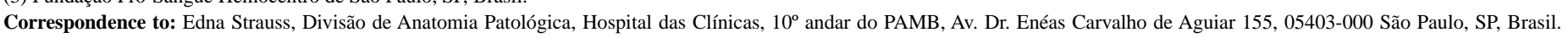
e-mail: edna.strauss@hcnet.usp.br
} 
Liver biopsy was indicated in patients with levels of ALT equal or greater than 1.5 times the upper normal limit, at two consecutive occasions, with more than 30 days interval. Biopsy specimens were processed for routine histopathological examination, using four different stains Haematoxilin-Eosin, Masson's trichrome, Perls for iron and impregnation of the reticulin framework by silver salts. Staging and grading of all specimens were semiquantitative from 0 to 4 , in accordance with the criteria recently described by GAYOTTO et al. ${ }^{12}$ All this process was blind, that means without knowledge of HGV status. Fibrosis progression index (FPI) could be calculated only in those cases with a very well determined duration of infection.

FPI or fibrosis progression rate per year, indirectly estimated, is the ratio between the fibrosis stage in units (new classification of chronic hepatitis) and the estimated duration of infection in years. In this model, it is assumed that the patient has no fibrosis in the day of infection (F0) and that fibrosis progression rate is constant ${ }^{20}$. For example, in a patient with fibrosis stage 2 and 12 years duration of infection the fibrosis progression index is 0.166 units of fibrosis per year.

In order to compare the groups $\mathrm{HCV}+\mathrm{HGV}$ and $\mathrm{HCV}$ only, the scores of the variables: staging, portal infiltrate, portal activity and lobular activity were submitted to variance analyzes by Wilcoxon score test. The values of $p$ were obtained by the exact test of AGRESTI ${ }^{1}$. The procedure NPAR1WAY of the SAS system was utilized for the analysis of data.

\section{RESULTS}

HGV-RNA was detected in 7 of the 46 patients (15.2\%). Liver biopsy was performed in 22 patients, six of them with co-infection HGV and HCV. Comparative demographic data of patients with co-infection or hepatitis $\mathrm{C}$ only, submitted to histopathological examination, is depicted in Table 1. Distribution of age and gender was the same between the groups, as well as serum levels of ALT and GGT.

Blood transfusion was the most frequent source of infection, present in one case with the HCV / HGV association and in 6 with HVC only. Other possible sources of infection in the $\mathrm{HCV} / \mathrm{HGV}$ group were drug injections in one, tattooing in another and dentist manipulation in the fourth. In two patients no source of infection was found. Duration of infection was possible to be estimated in three patients of the HCV / HGV group and in seven of the control group. It has varied from 10 to 15 years in the HVC / HGV group, with a mean FPI of 0.110 and from 8 to 25 years in the hepatitis $\mathrm{C}$ group with a mean FPI of 0.130 .

No patients in both groups reached grade 4 either in staging or inflammatory grading, as shown in Table 2. Most of the patients had mild liver disease and comparing the sum of grades 0 and 1 with the sum of grades 2 and 3, we have detected that inflammatory activity was usually lower in peri-portal areas and higher in lobular areas. When statistical analysis was applied the mean score values for inflammation varied from 9.41 to 9.83 for $\mathrm{HVC}+\mathrm{HGV}$ and from 12.12 to 12.28 for HVC only. For staging (fibrosis) the mean score values were 11.25 for $\mathrm{HCV}$ only and 12.16 for $\mathrm{HCV}+\mathrm{HGV}$ (Table 3). Although no statistical differences could be detected in terms of stage or activity between patients with co-infection compared to isolated HCV infection, a low degree of inflammation was constantly present in the $\mathrm{HCV} / \mathrm{HGV}$ group.

\section{DISCUSSION}

The high prevalence of the association between HCV and HGV may be due to the fact that $\mathrm{HGV}$ is transmitted through the same routes as $\mathrm{HCV}$, specially multiple blood transfusions, drug injection or other parenteral routes ${ }^{9}$. Nevertheless the prevalence of $15.2 \%$ is in keeping with that reported in literature, that has varied from $8.1 \%^{8}$, to $20 \%{ }^{10}$ or $43 \%$, according to the epidemiology of the studied population. As we

Table 1

Comparative data between patients with co-infection HCV / HGV and patients with $\mathrm{HCV}$ infection alone

\begin{tabular}{llll}
\hline & $\begin{array}{l}\text { Co-infection } \\
\text { HCV / HGV }\end{array}$ & HCV infection & "p" \\
\hline Male (n) & 4 & 13 & \\
Female (n) & 2 & 3 & \\
Age (years) & $36.5 \pm 6.2$ & $38.1 \pm 9.4$ & 0.6582 \\
ALT (U/L) & $74.5 \pm 52.6$ & $72.7 \pm 46.3$ & 0.9445 \\
GGT (U/L) & $51.5 \pm 27.1$ & $68.5 \pm 51.4$ & 0.3298 \\
\hline
\end{tabular}

Table 2

Structural alterations and inflammatory activity in patients with co-infection HCV / HGV compared to HCV alone

\begin{tabular}{|c|c|c|c|c|c|c|c|c|}
\hline & & 0 & 1 & 2 & 3 & 4 & $(0+1)$ & $(2+3)$ \\
\hline \multirow[t]{2}{*}{ Staging } & Co-inf. & 1 & 4 & 1 & 0 & 0 & 5 & 1 \\
\hline & HCV only & 6 & 6 & 2 & 2 & 0 & 12 & 4 \\
\hline Portal & Co-inf. & 0 & 4 & 2 & 0 & 0 & 4 & 2 \\
\hline Infiltrate & $\mathrm{HCV}$ only & 3 & 3 & 8 & 2 & 0 & 6 & 10 \\
\hline Peri-P. & Co-inf. & 1 & 5 & 0 & 0 & 0 & 6 & 0 \\
\hline activity & $\mathrm{HCV}$ only & 4 & 6 & 3 & 3 & 0 & 10 & 9 \\
\hline Lobular & Co-inf. & 0 & 4 & 1 & 1 & 0 & 4 & 2 \\
\hline activity & HCV only & 1 & 3 & 9 & 3 & 0 & 4 & 12 \\
\hline
\end{tabular}

Co-inf. = Co-infection by HCV and HGV; Peri-P = Peri-Portal 
Table 3

Results of the 4 histological variables, according to Wilcoxon variance analysis

\begin{tabular}{llcccc}
\hline Variable & Groups & Sum of scores & Standard Deviation & Mean score & $\mathrm{p}$ \\
\hline Staging & HCV + HGV & 73.0 & 12.66 & 12.16 & 0.8628 \\
& HCV only & 180.0 & 12.66 & 11.25 & \\
\hline Portal infiltrate & HCV +HGV & 59.0 & 12.66 & 9.83 & 0.4415 \\
& HCV only & 194.0 & 12.66 & 12.12 & 0.4291 \\
\hline Peri-portal activity & HCV+HGV & 58.0 & 12.57 & 9.66 & 0.3503 \\
& HCV only & 195.0 & 12.57 & 12.18 & 9.41 \\
\hline Lobular activity & HCV+HGV & 56.5 & 12.71 & 12.28 & \\
& HCV only & 196.5 & 12.71 & & \\
\hline
\end{tabular}

have studied blood donors with mild forms of chronic hepatitis $\mathrm{C}$, our prevalence is similar to the $10 \%$, found in Brazilian healthy blood donors ${ }^{15}$.

Our patients had no symptoms but due to high levels of ALT, sometimes associated with elevated GGT, they were submitted to liver biopsy in order to decide about the treatment for hepatitis C. Evaluation of the histological variables is generally accepted as the main parameter for treatment indication and patients with grades 0 or 1 in all these parameters should not be submitted to the anti-viral treatment available so far?.

The main parameter to evaluate progression of liver disease is the development of fibrosis ${ }^{21}$. At histology, stage grade 2 means the presence of fibrous septa out of the portal space, whereas in grades 0 and 1 fibrosis is respectively absent and restricted to portal area. Considering this variable, our co-infected patients behaved exactly the same as those infected only by HCV.

Analyzing the fibrosis progression index, the more recent and accepted way to evaluate the progression of hepatitis $\mathrm{C}^{21}$ we have found similar results for co-infected and control groups. The index of 0.110 for co-infection and 0.130 for hepatitis $\mathrm{C}$ characterize our patients as "slow fibrosers". In fact, the mean values found in the group of 1157 pre-treatment cases of POYNARD et al. was $0.252^{20}$.

Analyzes of the necroinflammatory activity according to the METAVIR classification has the advantage of combining the scores in the three areas giving a single number to express this variable ${ }^{4}$. Nevertheless, as a disadvantage, we lose the possibility of interpreting and correctly appreciate the real value of inflammation in the three different areas. Using the Brazilian consensus for the classification of chronic hepatitis we have analyzed inflammation separately in portal, peri-portal (or interface) and lobular or parenchymal areas ${ }^{12}$. Although scores 2 and 3 were more frequently found in lobular than in peri-portal areas, in both groups of patients the statistical analysis did not show significant differences. Mean score values for $\mathrm{HCV}+\mathrm{HGV}$ group were systematically lower than $\mathrm{HCV}$ alone, but also without statistical significance.

Similarly to what is described by other authors ${ }^{10,11,28}$ we could not detect a synergism between $\mathrm{HCV}$ and $\mathrm{HGV}$ and although not statistically significant, the necro-inflammatory activity was, in this small group of patients, a little lower in the co-infected patients. There are doubts about the pathogenicity of $\mathrm{HGV}^{6,14,19,24}$ and even if $\mathrm{HGV}$ is really a hepatropic virus with replication within liver cells. PESSOA et al. ${ }^{18}$ have shown that levels of HGV RNA in liver and serum were similar in patients with $\mathrm{HGV}$ infection alone compared with $\mathrm{HGV} / \mathrm{HCV}$ co-infection. Differently from $\mathrm{HCV}$, the median liver/serum levels of HGV RNA were less than unity, what is consistent with serum contamination of liver tissue, leading to the conclusion that liver is not the main site of $\mathrm{HGV}$ replication.

Although there are no clues for a protective function of $\mathrm{HGV}$ in hepatitis $\mathrm{C}$, since it does not affect $\mathrm{HCV}$ replication, the recent findings of mortality reduction in patients co-infected with HIV + HGV, compared with those with HIV alone ${ }^{29,30}$, claims for a better evaluation of hepatic histology in patients co-infected with HGV. Our results, showing that co-infection does not induce a more aggressive liver disease, supports the hypothesis of no pathogenicity of HGV.

\section{RESUMO}

\section{Histologia hepática na co-infecção do vírus da hepatite C (VHC) e vírus da hepatite $\mathrm{G}$ (VHG)}

As escassas informações sobre histologia hepática na co-infecção do vírus da Hepatite C (VHC) e vírus da Hepatite G (VHG) nos levou a investigar o RNA-VHG em 46 doadores de sangue com hepatite $\mathrm{C}$, dos quais 22 com biópsia hepática: co-infecção VHC / VHG $(n=6)$ e infecção isolada do VHC $(\mathrm{n}=16)$. Além de estadiamento e gradação da atividade inflamatória nas áreas portal, peri-portal e lobular, segundo o Consenso Brasileiro, calculamos também o índice de progressão da fibrose. Os pacientes estudados não apresentavam sintomas ou sinais físicos de doença hepática. A prevalência da co-infecção VHC / VHG foi de 15,2\%. A maior parte dos pacientes apresentava-se com lesão hepática discreta e o índice de progressão da fibrose, calculado apenas nos pacientes com duração conhecida da infecção, foi de 0,110 para os co-infectados e de 0,130 para aqueles com infecção isolada pelo VHC, caracterizando esses pacientes como "fibrosantes lentos". Não foram encontradas diferenças estatísticas entre os grupos, apesar de menor grau de inflamação em todas as áreas analisadas, nos casos de co-infecção. Em conclusão, a coinfecção VHC / VHG não induz o surgimento de lesão hepática mais grave, favorecendo a hipótese de que o VHG não é patogênico. 


\section{REFERENCES}

1. AGRESTI, A. - A survey of exact inference for contingency tables. Statist. Sci., 7: 131177, 1992.

2. ALTER, H.J. \& SEEFF, L.B. - Recovery, persistance and sequelae in hepatitis C virus infections: a perspective on long-term outcome. Sem. Liver Dis., 20: 17-35, 2001.

3. ALTER, H.J. - The cloning and clinical implications of HGV and HGBV-C. New Engl. J. Med., 334: 1536-1537, 1996.

4. BEDOSSA, P. \& POYNARD, T. - An algorithm for the grading of activity in chronic hepatitis C. The METAVIR Cooperative Study Group. Hepatology, 24: 289-293, 1996.

5. BERENGUER, M.; TERRAUL, N.A.; PIATAK, M. et al. - Hepatitis G virus infection in patients with hepatitis $\mathrm{C}$ virus infection undergoing liver transplantation. Gastroenterology, 111: 1569-1575, 1996.

6. BOWDEN, S. - New hepatitis viruses: contenders and pretenders. J. Gastroent. Hepat., 16: $124-131,2001$.

7. EASL - International Consensus Conference on Hepatitis C. Paris, 26-28, February 1999. Consensus Statement. European Association for the Study of the Liver. J. Hepat. 30: $956-961,1999$.

8. ENOMOTO, M.; NISHIGUCHI, S.; FUKUDA, K. et al. - Characteristics of patients with hepatitis $\mathrm{C}$ virus with and without $\mathrm{GB}$ virus $\mathrm{C} /$ hepatitis $\mathrm{G}$ virus co-infection and efficacy of Interferon alfa. Hepatology, 27: 1388-1393, 1998.

9. FEUCHT, H.-H.; ZOLLNER, B.; POLYWKA, S. et al. - Distribution of hepatitis G viremia and antibody response to recombinant proteins with special regard to risk factors in 709 patients. Hepatology, 26: 491-494, 1997.

10. FRIED, M.W.; KHUDYAKOV, Y.E.; SMALLWOOD, G.A. et al. - Hepatitis G virus coinfection in liver transplantation recipients with chronic hepatitis $\mathrm{C}$ and nonviral chronic liver disease. Hepatology, 25: 1271-1275, 1997.

11. GARCIA Jr., F.; GARCIA, F.; ROLDAN, C. et al - Detection of HCV and GBV-CHGV RNA in peripheral blood mononuclear cells of patients with chronic type $\mathrm{C}$ hepatitis. Microbios, 103: 7-15, 2000 .

12. GAYOTTO, L.C.C. \& Comité SBP/SBH - Visão histórica e consenso nacional sobre a classificação das hepatites crônicas. Gastroen. End. digest., 19: 137-140, 2000.

13. KANDA, T.; YOKOSUKA, O.; EHATA, T. et al. - Detection of GBV-C RNA in patients with non A-E fulminant hepatitis by reverse-transcription polymerase chain reaction. Hepatology, 25: 1261-1265, 1997.

14. KARAYIANNIS, P. \& THOMAS, H.C. - Current status of hepatitis G virus (GBV-C) in transfusion: is it relevant? Vox Sang. (Basel), 73: 63-69, 1997.

15. LAMPE, E.; DE OLIVEIRA, J.M.; PEREIRA, J.L. et al. - Hepatitis G virus (GBV-C) infection among Brazilian patients with chronic liver disease and blood donors. Clin. diagn. Virol., 9: 1-7, 1998.
16. LINNEN, J.; WAGES Jr., J.; ZHANG-KECK, Z.Y. et al. - Molecular cloning and disease association of hepatitis $G$ virus: a transfusion-transmissible agent. Science, 271: 505 $508,1996$.

17. MIYAKAWA,Y. \& MAYUMI, M. - Hepatitis G virus: a true hepatitis virus or an accidental tourist? New Engl. J. Med., 336: 795-796, 1997.

18. PESSOA, M.G.; TERRAULD, N.A.; DETMER, J. et al. - Quantitation of hepatitis G and $\mathrm{C}$ viruses in the liver: evidence that hepatitis $\mathrm{G}$ virus is not hepatotropic. Hepatology, 27: 877-880, 1998.

19. PESSOA, M.G.; TERRAULT, N.A.; FERREL, L.D. et al. - Hepatitis G virus in patients with cryptogenic liver disease undergoing liver transplantation. Hepatology, 25: 1266$1270,1997$.

20. POYNARD, T.; BEDOSSA, P. \& OPOLON, P. - Natural history of liver fibrosis progression in patients with chronic hepatitis C. The OBSVIRC, METAVIR, CLINIVIR and DOSVIRC Groups. Lancet, 349: 825-832, 1997.

21. POYNARD, T.; RATZVI, V.; BENMANOV, Y. et al. - Fibrosis in patients with chronic hepatitis C: detection and significance. Semin. Liver Dis., 20: 47-55, 2000.

22. RODRIGUEZ-INIGO, E.; TOMAS, J.F.; GOMEZ-GARCIA DE SORIA, V. et al. Hepatitis $C$ and $G$ virus infection and liver dysfunction after allogeneic bone marrow transplantation: results from a prospective study. Blood, 90: 1326-1331, 1997.

23. SEIDL, S.; KOENIG, B.; REINHARDT, G. et al. - Higher detection rate of hepatitis G and $\mathrm{C}$ virus RNA in liver tissue than in serum of deceased injection drug users. Int. J. legal Med., 112: 35-38, 1999.

24. STRAUSS, E. - Hepatite G: ficção científica ou realidade clínica. Hemat. Hemoter., 1 27-28, 1996.

25. STRAUSS, E. - Hepatite C. Rev. Soc. bras. Med. trop., 34: 69-82, 2001.

26. TEPPER, J.L.; FEINMAN, S.V.; D'COSTA, L.; SOOKNANNAN, R. \& PRUZANSKI, W. - Hepatitis G and hepatitis C RNA viruses coexisting in cryoglobulinemia. J. Rheum., 25: 925-928, 1998.

27. THEODORE, D. \& LEMON, S.M. - GB-virus C, hepatitis G virus, or human orphan flavivirus? Hepatology, 25: 1285-1286, 1997.

28. THIERS, V.; POL, S.; PERSICO, T. et al. - Hepatitis G virus infection in hepatitis C virus-positive patients co-infected or not with hepatitis B virus and/or human immunodeficiency virus. J. viral Hepatitis, 5: 123-130, 1998.

29. TILLMANN, H.L.; HEIKEN, H.; KNAPIK-BOTOR, A. et al. - Infection with GB virus $\mathrm{C}$ and reduced mortality among HIV-infected patients. New Engl. J. Med., 345: 761-762, 2001.

30. XIANG, J.; WUNSCHMANN, S.; DIEKEMA, D.J. et al. - Effect of co-infection with GB virus $C$ on survival among patients with HIV infection. New Engl. J. Med., 345: 707-714, 2001.

Received: 29 November 2001

Accepted: 04 January 2002 